\title{
Statistical Analysis of the Mycorrhizae Impact on Communities of Alpine Meadows
}

\author{
Farish N.R., Lavrenov N.G. \\ Department of Geobotany, Biological Faculty, Moscow State University, Moscow, Russia \\ farish.nina.r@gmail.com
}

\begin{abstract}
The symbiotic association of mycelial fungus with the roots of higher plants (mycorrhiza) has a large and often ambiguous influence on plant communities and their structure. Mycorrhiza acts simultaneously on many features of the community, and, therefore, the assessment of its influence is not an easy task. It requires carefully planned experiments and the use of special methods of statistical analysis. Following a four-year experiment at the high-altitude station of the Moscow State University "Malaya Khatipara" (Teberda Nature Reserve), this article presents the results of data analysis, including two-way replicated analysis of variance (ANOVA). The alpine meadow communities were subjected to treatment with fungicides in order to suppress fungal colonization. It was found that suppression of mycorrhizae always leads to a decrease in the number of forbs dependent on mycorrhizal fungi, an increase in the number of predominantly non-mycorrhizal sedges, and the dynamics of grasses abundance after suppression of mycorrhiza may differ depending on their initial position in the community. Our results also point out the positive role of mycorrhiza in forming species richness in communities of the alpine belt of mountains.
\end{abstract}

Key words: mycorrhizal infection, data analysis, ANOVA, alpine meadow communities, Teberda Nature Reserve.

\section{Статистический анализ влияния микоризы на сообщества альпийских лугов}

\author{
Фариш Н.Р., Лавренов Н.Г.
}

Кафедра геоботаники, Биологический факультет, МГУ имени М.В. Ломоносова, Москва, Россия

Симбиотическая ассоциация мицелия гриба с корнями высших растений (микориза) оказывает большое и зачастую неоднозначное влияние на растительные сообщества и их структуру. Микориза одновременно действует на многие характеристики сообщества, поэтому оценка ее влияния оказывается непростой задачей, требует тщательного планирования эксперимента и применения специальных методов статистического анализа. В работе изложены результаты анализа, в том числе двухфакторного дисперсионного анализа с повторностями, четырехлетнего эксперимента на высокогорном стационаре МГУ «Малая Хатипара» (Тебердинский заповедник). В эксперименте сообщества альпийских лугов были подвергнуты обработке фунгицидами с целью подавления грибных компонентов. Было выявлено, что подавление микоризы всегда приводит к снижению численности разнотравья, зависимой от микоризных грибов, увеличению численности преимущественно немикоризных осок, а динамика злаков при подавлении микоризы может быть различна в зависимости от их изначального положения в сообществе. Наши результаты также указывают на положительную роль микоризы в формировании видового разнообразия сообществ альпийского пояса гор и на наличие транспорта между ювенильными и взрослыми особями с помощью микоризной сети.

Ключевые слова: микоризная инфекиия, анализ данных, ANOVA, сообщества альпийских лугов, Тебердинский заповедник.

\section{Introduction}

Mycorrhiza is considered to be one of the key drivers determining the structure and diversity of natural plant communities. Its influence is often quite ambiguous. There are a lot of factors that affect the interaction of fungal components with plant communities, in particular, such factors as soil richness, especially nitrogen and phosphorus content, humidification, acidity and aeration [12]. Such a complex combination of variables means that the 
dynamics of communities in experiments based on the suppression of mycorrhizas can vary significantly depending on the conditions of their vegetation. In addition, it should be borne in mind that different species of plants have different rates of mycorrhizal infection.

Mycorrhizae are widespread in the alpine zone [16], but there are not so many studies of their influence on the alpine communities. Under conditions of resource limitation, in the highlands plants use two alternative strategies for transporting organic content to seedlings from adult plants, namely through the mycorrhizal network or through clonal reproduction [14]. Therefore, there are almost as many non-mycorrhizal plants as obligate mycotrophs in the alpine meadows [1, 4, 11].

Standard methods for studying the effect of mycorrhizae on the community are divided into two types of experiments: fertilization and the application of fungicides. The second approach was used in our work. There have been several hypotheses put forward, based on the results of similar studies with suppression of mycorrhiza in meadow communities of poor soils (including in alpine meadows) (see below). It was expected that the 4-year application of fungicides would result in the following:

1. In communities dominated by mycorrhizadependent plants: a decrease in the abundance of dominants, an increase in subdominants. An increase in the abundance of dominants was expected in communities dominated by less mycorrhiza-dependent species, together with a decrease in subdominants $[2,7$, $8,10,12]$.

2. An increase in the coverage of less mycorrhizadependent plants (grasses and sedges), and a decrease in coverage of herbs dependent on mycorrhizal symbiosis [5].

3. Decline in species richness in communities with mycotrophic dominants, an increase in the opposite case $[5,6,8]$.

\section{Methods and materials}

\subsection{Study area}

The study area is located in the alpine belt of the Teberda Biosphere Reserve, Karachai, North-western Caucasus, Russia. The reserve occupies 83000 ha and has an altitudinal range from 1350 to $4046 \mathrm{~m}$ a.s.l. There are 1300 species of vascular plants known in the reserve. The sample plots were located in the highaltitude station on the Malaya Khatipara Mt. $\left(43^{\circ} 27^{\prime} \mathrm{N}\right.$, $\left.41^{\circ} 41^{\prime} \mathrm{E}\right)$. The altitude range is $2300-2900 \mathrm{~m}$. The climate is temperate mountainous, type $\mathrm{X}(\mathrm{VI})$. Mean annual temperature is about $-1.2^{\circ} \mathrm{C}$, and mean annual precipitation $1400 \mathrm{~mm}$. The average temperature of the warmest month (August) is $+8.3^{\circ} \mathrm{C}$, but frosts may occur throughout the summer. South winds prevail, thus the south-facing slopes are windward, whereas the north-facing slopes are leeward and experience heavy snow accumulation. Siliceous rocks prevail in the
Teberda Reserve, among which biotit schists and granites are most significant [13].

\subsection{Description of the field experiment}

The data were collected over a 4-year period from 2014 to 2017. The sample plots were located in 4 main communities of alpine meadows:

1. Alpine lichen heaths (ALH) are communities of low productivity and are confined to windward crests and mountain slopes.

2. Festuca varia - grassland (FVG) are firm-bunchgrass productive communities with absolute dominance of Festucavaria.

3. Geranium gymnocaulon - Hedysarum caucasicum meadows (GHM) are forb meadows with the greatest aboveground production. They occupy the lower parts of the slopes with considerable snow accumulation.

4. Alpine snowbed communities (SBC) are confined to negative elements of mesorelief and they have low species richness indices and low annual production due to the short vegetation period.

Indices of intensity of mycorrhizal infection are supposed to increase in a line of communities SBCALH-FVG-GHM. Low indices for the first two communities are associated with adverse soil conditions for fungi [1].

In each of the four communities 20 plots of $25 \times 25 \mathrm{~cm}$ were established at a distance of $50-100 \mathrm{~cm}$ from each other. The plots were grouped into two parallel transects. The plots were randomly distributed to a control or experimental group. The fungicide "Benomyl" was introduced into the soil on the experimental plots at the rate of $2.85 \mathrm{~g}$ of preparation per plot to suppress the mycorrhizal fungi. The decomposition of Benomyl in the soil increases the nitrogen content. Therefore, tryptophan, which is not toxic to fungi, was applied to the control plots in a volume $2.1 \mathrm{~g}$ per plot, so that the amount of nitrogen introduced was the same. Both substances in the form of powders were diluted at the rate of $600 \mathrm{ml}$ per site. Before the application of the fungicide and tryptophan, all shoots were counted on each plot every year and the species of the plant as well as its ontogenetic stage (juvenile, virginal and generative) was determined for each shoot.

\subsection{Data analysis}

For each community, the dynamics of the number of shoots by years on experimental and control sites was analyzed. The number of shoots was grouped according to the ontogenetic stages (juvenile, virginile, generative) and to the systematic groups of species (grasses, sedges and forbs). The means and standard errors were calculated for the control and experimental plots separately for each year (Fig. 1).

A visual graphical analysis of the dominants' abundance dynamics in communities was made. We also performed a graphical analysis of the species richness dynamics in each community. 
We used two-way ANOVA to estimate the differences in numbers of shoots. The analysis was carried out for each site for the number of shoots averaged over the years. For each of the four communities, two general analyses were made. The control and experiment groups were used as the first factor. The ontogenetic stages (juvenile, virginal, generative) were regarded as the second factor in the first case, meanwhile systematic groups (grasses, sedges, forbs) were considered as the second factor in the second case.

Tests of normality and homogeneity of within-group variances were performed. The data were converted by taking the natural logarithm of each observation to meet the assumptions of the analysis. The formula $\ln (x+1)$ was used since the data include zero. If the ANOVAs showed significant differences between ontogenetic stages or systematic groups, pairwise comparisons were made using the Tukey-Kramer test.

Further, additional analyses were carried out where the control and experimental groups were taken as the first factor, and the type of community as the second factor. Thus, 6 analyzes were made for each of the groups (sedges, grasses, forbs and 3 variants of ontogenetic stages) in the same way as described above.

\section{Results}

\subsection{Abundance analysis}

The results of the dynamics analysis of the abundance of shoots indicate that on alpine snowbeds there is a decrease in the number of grasses and forbs on the experimental plots compared with the control ones (Fig. 1). There is an increase in the number of grasses in the experiment in alpine lichen heaths, and the dynamics of the remaining groups differs insignificantly in control and experiment. In the Festuca varia grasslands, the number of grasses and sedges is higher in areas where fungicides have been introduced, but it is difficult to make certain conclusions about the dynamics of forbs because the differences in abundance over the years exceed the differences between experiment and control. On the Geranium gymnocaulon - Hedysarum caucasicum meadows, the negative dynamics is traced in the forb's abundance whereas positive dynamics, albeit not so obvious, is traced in the abundance of sedges on the experimental plots in comparison with the control ones (Fig. 1).

Thus, we observe that the suppression of mycorrhizae affects negatively the dynamics of forbs. In general, plants that form this group are less prone to clonal reproduction and, therefore, are more dependent on mycorrhizal symbiosis. Sedges are considered to be non-mycorrhizal or almost non-mycorrhizal $[3,9,15$, 16] so when they are treated with fungicides, they become more competitive in comparison with the representatives of forbs, and their abundance increases. The rates of mycorrhizal infection in grasses are often large [1] however, representatives of this group are able to reproduce clonally, that is, to use the second way of transporting elements of mineral nutrition between adults and young individuals. In a community where the grasses are the only dominants (FVG), the mycorrhiza suppression causes them to become more abundant, and in the communities where the grasses are subdominants, the dynamics is negative.

\subsection{ANOVA results}

The two-way ANOVA showed that there were significant differences in shoot numbers between control and experimental plots for all communities, except for ALH (Table 1). The degree of mycorrhiza in this community is not high [1], which may be the reason for the absence of statistically significant differences. It may take more time to manifest the dynamics in this community.

Table 1. Results of two variants of ANOVA 1) control/experiment $\times$ ontogenetic stage and 2) control/experiment $\times$ group of species. SBC Alpine snowbed communities, ALH - Alpine lichen heaths, FVG - Festuca varia - grassland, GHM Geranium gymnocaulon - Hedysarum caucasicum meadows

\begin{tabular}{|l|c|l|l|l|c|}
\hline & Variant & $\begin{array}{r}\text { Source of } \\
\text { variation }\end{array}$ & $F$ & $P$ & $d f$ \\
\hline \multirow{2}{*}{ SBC } & 1 & Contr./Exp. & 3.44 & 0.069 & 1 \\
\cline { 2 - 6 } & 2 & Ont. stage & 443.60 & 3.060 & 1 \\
\hline \multirow{2}{*}{ ALH } & 1 & Contr./Exp. & 0.55 & 0.463 & 1 \\
\cline { 2 - 6 } & 2 & Ont. stage & 162.31 & 1.457 & 1 \\
\hline \multirow{2}{*}{ FGV } & 1 & Contr./Exp. & 0.29 & 0.595 & 1 \\
\cline { 2 - 6 } & 2 & Ont. stage & 664.90 & 9.240 & 1 \\
\hline \multirow{2}{*}{ GHM } & 1 & Contr./Exp. & 2.51 & 0.119 & 1 \\
\cline { 2 - 6 } & 2 & Ont. stage & 115.52 & 3.105 & 1 \\
\hline
\end{tabular}

$F$ - the variance ratio, $P$ - Type I error, $d f$ is the number of degrees of freedom.

ANOVAs didn't show any significant interaction effects for all communities.

ANOVA showed significant differences in shoot numbers for systematic groups (grasses, sedges, forbs) for FVG community and for ontogenetic groups for all communities except ALH.

The three groups compared are not equally represented in the data in the case of ontogenetic stages (juvenile, virginal, generative) as well as in the case of systematic groups (grasses, sedges, forbs), which also makes analysis difficult. Therefore, we conducted 


\section{Alpine snowbed communities}
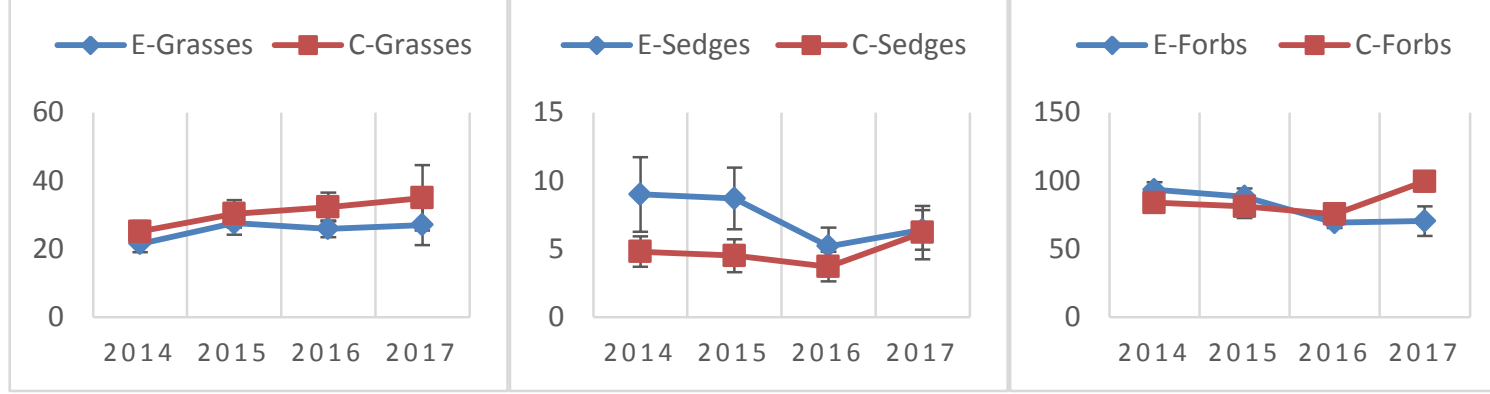

\section{Alpine lichen heaths}
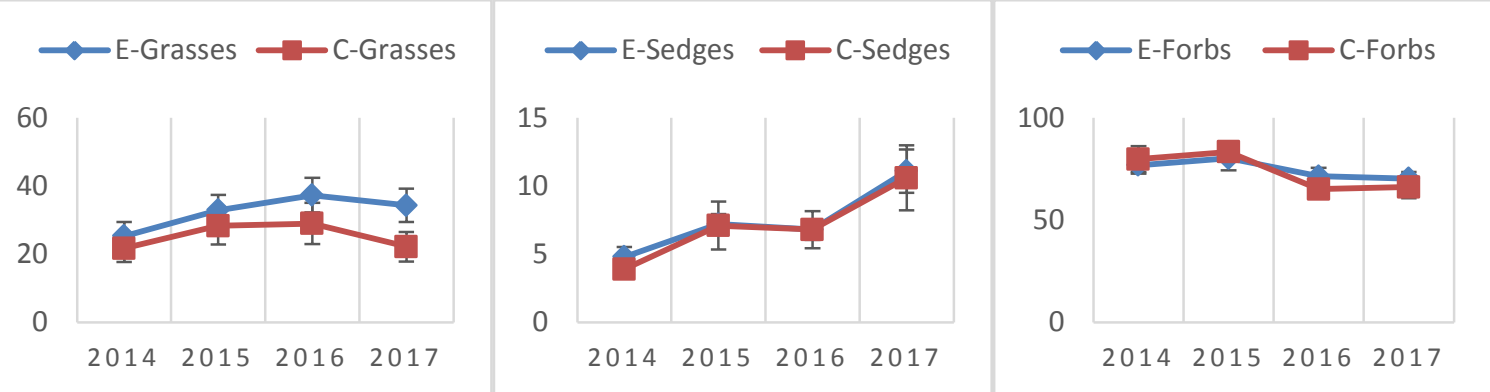

\section{Festucavaria-grassland}
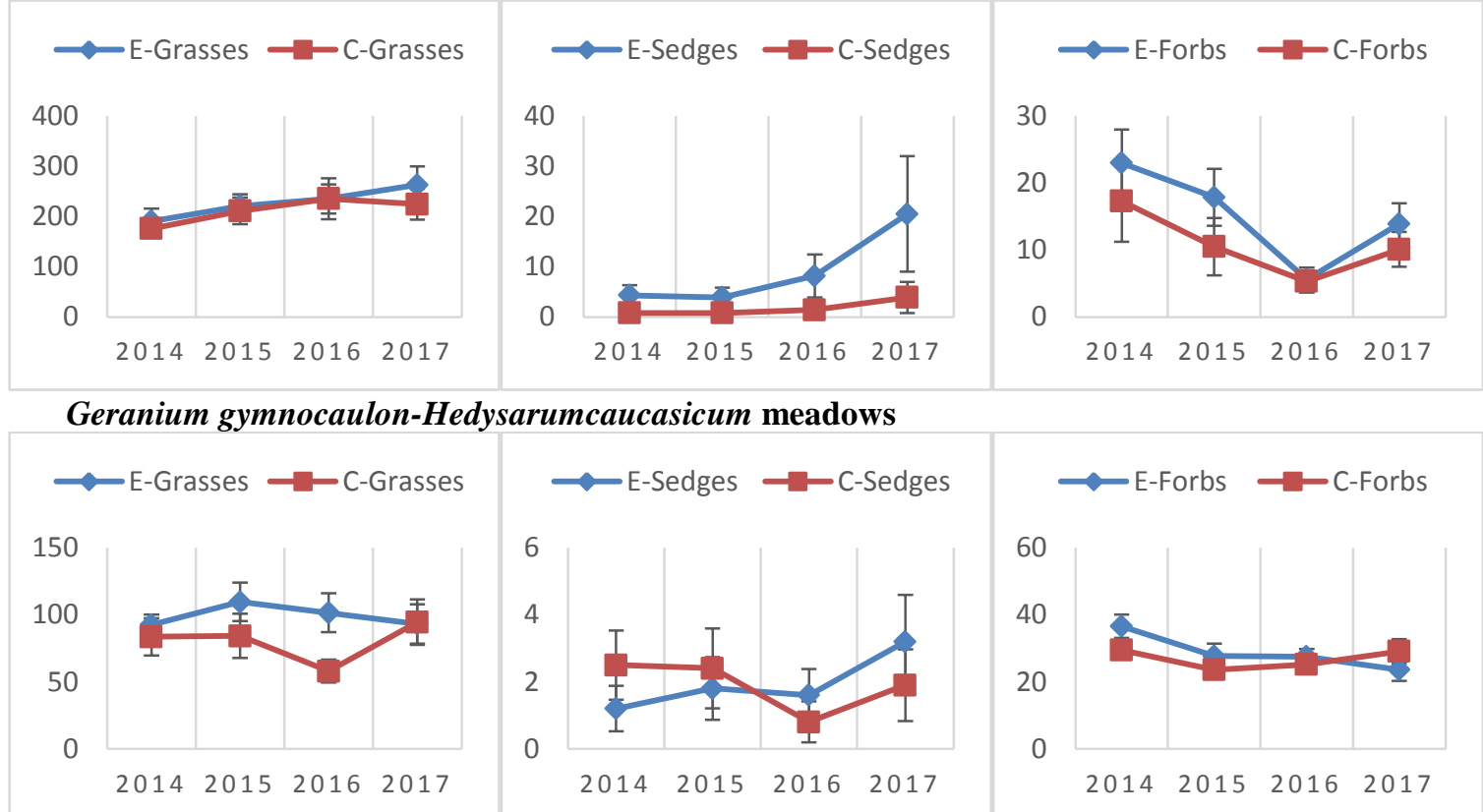

Fig. 1. Dynamics of number of shoots of grasses, sedges and forbs in 4 communities of alpine meadows in control and experimental plots. The ordinates are the mean number of shoots and the abscissae are the year. The bars indicate standard errors.

additional ANOVAs to analyse these groups separately. Experiment-control and type of community were taken as factors, and numbers of shoots were taken as a response. Significant differences were found for sedges and for generative ontogenetic stage (Table 2). These differences were masked in the previous analysis by better represented in the data groups - grasses and virginialontogenetic stage. In the analysis with generative ontogenetic stage taken as response, significant interaction of the factors was revealed. The interaction plot (Fig. 2) for this case shows that the difference in numbers of shoots on control and experimental sites increases in the SBC-ALH-FVG series, and then decreases in GHM. The most meaningful results are observed for the FVG community. In the first two communities, this is probably due to a low degree of mycorrhiza [1]. An unexpectedly low degree of mycorrhizal infection was also noted for GHM by other authors [14]. It was due to soil disturbances, and, therefore, the fungal mycelium damage. It may be that our results also reflect this feature of the community. 


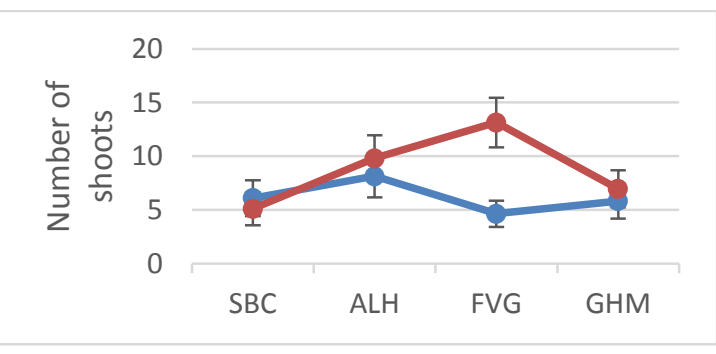

Fig. 2. The mean number of generative shoots per plot in the control and experiment for the communities studied. Blue indicates control, red experiment. The bars represent $95 \%$ confidence intervals.

Table 2. The results of ANOVA of control / experiment and type of community. The response is the number of shoots for the generative stage, the number of shoots of the sedges

\begin{tabular}{|c|c|c|c|}
\hline Source of variation & Stat. & Sedges & Generative \\
\hline \multirow{3}{*}{ Control / experiment } & $F$ & 5.45 & 7.14 \\
\cline { 2 - 4 } & $p$ & 0.022 & 0.009 \\
\cline { 2 - 4 } & $d f$ & 1 & 1 \\
\hline \multirow{3}{*}{ Community } & $F$ & 9.02 & 3.31 \\
\cline { 2 - 4 } & $p$ & 0.000 & 0.025 \\
\cline { 2 - 4 } & $d f$ & 3 & 3 \\
\hline
\end{tabular}

In all communities except GHM, the abundance of sedges is higher on experimental plots (Table 3), which is explained by the low degree of mycorrhization of this group and that its competitiveness increases under conditions of suppressed mycorrhiza. The number of generative shoots is also greater on the experiment plots. Suppression of mycorrhizae reduces the role of seed reproduction (for mycorrhiza-dependent species the presence of mycorrhizal fungi hyphae is necessary for sprouts), giving an advantage to those species that are capable of clonal reproduction. However, we observe the opposite. We assume that this may be due to the fact that the dynamics by years and the increase in the number of generative shoots were not considered in the analysis of variance - this is the reaction of plants to stressful conditions of lack of elements of mineral nutrition in the absence of mycorrhiza.

Table 3. Mean number of shoots on the control and experiment plots ${ }^{*}$. Names of communities are the same as in Table. 1. The back-transformed means are given

\begin{tabular}{|c|c|c|c|c|c|}
\hline \multicolumn{7}{|c|}{ Generative } \\
\hline & SBC & ALH & FVG & GHM & $\sum$ \\
\hline Control & 6.10 & 8.14 & 4.63 & 5.82 & 6.06 \\
\hline Experiment & 5.10 & 9.81 & 13.14 & 6.95 & 8.28 \\
\hline \multicolumn{5}{|c|}{ Sedges } \\
\hline & SBC & ALH & FVG & GHM & $\sum$ \\
\hline Control & 3.46 & 5.32 & 0.62 & 1.31 & 2.21 \\
\hline Experiment & 6.29 & 7.18 & 3.65 & 1.18 & 3.96 \\
\hline
\end{tabular}

*There are 10 control and experimental plots in each community

\subsection{Dynamics of dominants}

Comparison of the dynamics of dominant abundance confirmed the hypothesis that mycorrhizal suppression has a different affect depending on the intensity of mycorrhizal infection and the capacity for clonal reproduction of species. The suppression of mycorrhizae affects the abundance of forbs dominants negatively (Potentilla crantzii, Sibbaldia procumbens in SBC, Antennaria dioica in ALH, Geranium gymnocaulon in GHM), with the exception of Hedisarum caucasicum, which abundance did not change. As can be seen from Table 4, the rates of mycorrhiza infection of these species are high. Grasses are able to reproduce clonally, therefore, suppression of mycorrhizae does not cause a significant decrease in abundance regardless of the mycorrhizal infection intensity (Catabrosella variegata in SBC, Carex umbrosa in

Table 4. Dynamics of community dominants. Red indicates the species whose numbers have decreased, green - increased, gray - have not changed. The average intensity of mycorrhizal infection and the mean error are indicated in parentheses (according to [1])

\begin{tabular}{|c|c|c|}
\hline SBC & $\begin{array}{l}\text { Catabrosella variegata } \\
\qquad(10 \pm 3)\end{array}$ & $\begin{array}{c}\text { Potentilla crantzii } \\
(36 \pm 3) \\
\text { Sibbaldia } \\
\text { procumbens } \\
(55 \pm 3)\end{array}$ \\
\hline \multirow[t]{2}{*}{$\mathrm{ALH}$} & $\begin{array}{c}\text { Festuca ovina }(43 \pm 3) \\
\text { Vacciniumvitis-idaea } \\
(30 \pm 2)\end{array}$ & \multirow[t]{2}{*}{$\begin{array}{c}\text { Antennaria dioica } \\
(61 \pm 3)\end{array}$} \\
\hline & Carex umbrosa & \\
\hline FVG & $\begin{array}{l}\text { Festuca varia }(51 \pm 3) \\
\text { Nardus stricta }(54 \pm 3)\end{array}$ & \\
\hline \multirow[t]{2}{*}{ GHM } & $\begin{array}{c}\text { Festuca brunescens } \\
(28 \pm 3) \\
\text { Hedisarum caucasicum } \\
(47 \pm 5)\end{array}$ & \multirow[t]{2}{*}{$\begin{array}{l}\text { Geranium } \\
\text { gymnocaulon } \\
\quad(57 \pm 3)\end{array}$} \\
\hline & Nardus stricta $(54 \pm 3)$ & \\
\hline
\end{tabular}

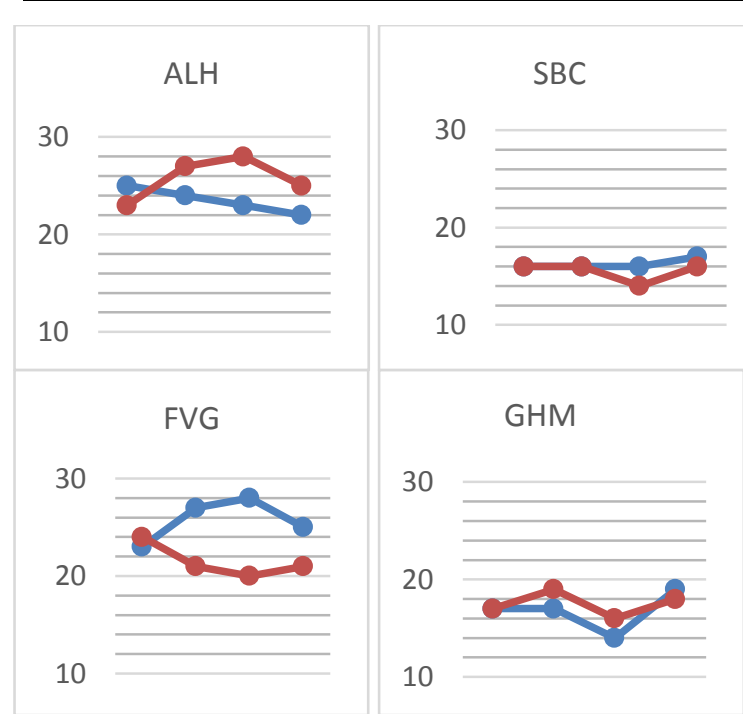

Fig. 3. Species richness. Names of communities are the same as in Table. $1 . Y$-axes are the number of species. $X$-axes are years. The blue lines indicate control, the red ones - experiment. 
ALH, Festuca varia and Nardus stricta in FVG, Festuca brunescens in GHM), and in some cases their abundance even increases (Festuca ovina in ALH, Nardus stricta in GHM) (Table 4). The abundance of the only sedge represented (Carex umbrosa) does not change. This can be explained by the ability of sedges to reproduce clonally and none or minor rates of mycorrhiza infection, which is not indicated in the source, because sedges were considered nonmycorrhizal by the authors [1]. There was also a slight increase in the abundance of Vacciniumvitis-idaea in ALH, a species that has erycoid mycorrhiza and a relatively small degree of infection in comparison with dominant species of forbs.

\subsection{Species richness}

The results of the species richness analysis on the experimental plots in comparison with control ones are presented in Fig. 3:

1. There is a decrease in species richness in SBC and FVG. The dominants of the FVG are able to reproduce clonally and in the absence of mycorrhizal fungi they displace subdominant forbs. In SBC, the species richness also decreases - here the grasses are also quite abundant and are present among the dominants. The dynamics of the species richness is not so noticeable, probably because the community has the lowest rates of mycorrhization among the four considered by us.

2. In GHM, where forbs are dominant, species richness remains nearly the same. According to the results of studies by other authors $[7,8,10]$ in communities dominated by obligate mycorrhizaforming agents, such as Hedisarum caucasicum and Geranium gymnocaulon, mycorrhiza suppression can cause an increase in species richness. This is due to the fact that mycorrhiza-dependent species are more competitive in the presence of fungal components. Application of fungicides in such communities can cause an increase in species richness due to an increase in the contribution of subdominants.

3. In ALH there is an increase in species richness. Lichens (mainly Cetraria islandica) are one of the main dominants of this community. Fungicides have a negative effect on lichens [10]. It may be that the vacant niches previously occupied by lichens are being taken up by representatives of vascular plants, and, therefore, the species richness increases.

Thus, the results of our study indicate that mycorrhizas may make important contribution to species richness levels of the alpine communities.

\section{Conclusions}

As a result of the application of methods of statistical analysis, the following conclusions were drawn:

1. The forbs depend on mycorrhizal symbiosis to a greater extent than the sedges and grasses.

2 . The number of shoots of sedgs increases after suppression of mycorrhiza.
3. The dynamics of species richness after suppression of mycorrhizae can vary in different ways depending on the structure of the community. The species capacity for clonal reproduction and the intensity of mycorrhiza infection of dominants largely determines the structure of the community.

\section{Acknowledgements}

The authors are grateful to the scientific adviser Prof. Vladimir Onipchenko for help at all stages of the work and Drs. Vadim Smirnov and Larisa Khanina for consultations on data analysis and processing. We express our sincere gratitude to the Department of Geobotany for funding of the research.

\section{References}

1. Baikalova A.S., Onipchenko V.G. Mycosymbiotrophism of alpine species in the Teberda Reserve. Investigations of plant communities in nature reserves. Moscow: CNIL Glavokhoty RSFSR, 1988. P. 93-107 (in Russ.)

2. Bentivenga S.P., Hetrick B.A.D. Relationship between mycorrhizal activity, burning, and plant productivity in tallgrass prairie. Canadian Journal of Botany. 1991. V. 69. P. 2597-2602.

3. Blanke V., Bassin S., Volk M., Fuhrer J. Nitrogen deposition effects on subalpine grassland: the role of nutrient limitation and changes in mycorrhizal abundance. Actaoecologica. 2012. V. 45. P. 57-65. doi: 10.1016/j.actao.2012.09.002.

4. Cripps C.L., Eddington L.H. Distribution of mycorrhizal types among alpine vascular plant families on the Beartooth Plateau, Rocky Mountains, U.S.A., in reference to large scale patterns in arctic-alpine habitats. Arctic Antarct. Alp. Res. 2005. V. 37. P. 177-188. doi: $10.1657 / 1523-0430(2005) 037[0177$ : DOMTAA]2.0.CO;2.

5. Dostalek T., Pankova H., Munzbergova Z., Rydlova J. The Effect of AMF Suppression on Plant Species Composition in a Nutrient-Poor Dry Grassland. Plos One. 2013. V. 8. P. 1-11. doi: 10.1371/journal.pone.0080535.

6. Gange A.C., Brown V.K., Farmer L.M. A test of mycorrhizal benefit in an early successional plant community. New Phytologist. 1990. V. 115. P. 85-91.

7. Hartnett D.C., Wilson G.W.T. Mycorrhizae influence plant community structure and diversity in tallgrass prarie. Ecology. 1999. V. 80. P. 1187-1195. doi: 10.2307/177066.

8. Karanika E.D., Mamolos A.P., Alifragis D.A., Kalburtji K.L., Veresoglou D.S. Arbuscular mycorrhizas contribution to nutrition, productivity, structure and diversity of plant community in mountainous herbaceous grassland of northern Greece. Plant Ecology. 2008. V. 199. P. 225-234. doi: 10.1007/s11258008-9427-9. 
9. Muthukumar T., Udaiyan K., Shanmughavel P. Mycorrhiza in sedges - an overview. Mycorrhiza. 2004. V. 14. P. 65-77. doi: 10.1007/s00572-004-0296-3.

10. Newsham K.K., Watkinson A.R., West H.M., Fitter A.H. Symbiotic Fungi Determine Plant Community Structure: Changes in a LichenRich Community Induced by Fungicide Application. Funct. Ecol. 1995. V. 9. P. 442447. doi: $10.2307 / 2390007$.

11. Nozadze L.M. Mycotrophic herbaceous plants in some plant communities of the Kazbegidistric. High-altitude ecosystem of Kazbegi. Reports to the symposium. 1977. P. 53-58 (in Russ.).

12. Onipchenko V.G. Functional phytocenology: plant synecology. Moscow: Krasand, 2013. 576 p. (in Russ.)

13. Onipchenko V.G., Semenova G.V. Comparative analysis of the floristic richness of alpine communities in the Caucasus and the Central Alps. J. of Vegetation Science. 1995. V. 6. P. 299-304. doi: 10.2307/3236225.

14. Onipchenko V.G., Zobel M. Mycorrhiza, vegetative mobility and responses to disturbance of alpine plants in the Northwestern Caucasus. Folia Geobotanica. 2000. V. 35. P. 1-11.

15. Selivanov I.A. Mycosymbiotrophism as a form of consortium connections in the vegetative cover of the Soviet Union. Moscow: Nauka, 1981. 232 p. (in Russ.)

16. Smith, S.E., Read, D.J. Mycorrhizal Symbiosis. 3d ed. London: Academic Press, 2008. 804 p.

17. Van der Heijden M.G.A., Bardgett R.D., van Straalen N.M. The unseen majority: soil microbes as drivers of plant diversity and productivity in terrestrial ecosystems. Ecology Letters. 2008. V. 11. P. 296-310. doi: 10.1111/j.1461-0248.2007.01139.x. 